\title{
Localized Intracellular Polyphosphate Formation by Desulfovibrio gigas
}

\author{
By H. E. JONES AND LYN A. CHAMBERS \\ Baas Becking Geobiological Laboratory, Bureau of Mineral Resources, Canberra City, \\ A.C.T., 260 I, Australia
}

(Received I October 1974; revised 4 January 1975)

\begin{abstract}
SUMMAR Y
The dissimilatory sulphate-reducing bacterium Desulfovibrio gigas, frequently sub-cultured, often contained spherical granules which stained metachromatically with some basic dyes. The granules were examined in situ by transmission electron microscopy of whole organisms and thin sections. The granules were isolated from broken bacteria as a water-insoluble, non-crystalline, white material containing magnesium, phosphorus and organic carbon, but devoid of sulphur and nitrogen. The molar ratio of phosphorus to magnesium $(\mathrm{I} \cdot 17)$ was close to the proportions in magnesium tripolyphosphate. Infrared absorption spectra for the white material and magnesium tripolyphosphate were similar.
\end{abstract}

\section{INTRODUCTION}

During phase-contrast light microscopy of the dissimilatory sulphate-reducing bacterium Desulfovibrio gigas, which had been subcultured at three-weekly intervals for at least 2 years at $35{ }^{\circ} \mathrm{C}$ in medium B (Jones, I97I), spherical granules were frequently observed within the organisms. These granules were not apparent before the bacterium had undergone many subcultures, but were not a result of bacterial contamination since the purity of the culture and the characteristic morphology and physiology of the bacterium remained unchanged. This paper reports the structure, isolation and chemical analysis of the granules.

\section{METHODS}

Strains. The strains used were Desulfovibrio africanus (National Collection of Industrial Bacteria, NCIB840I), D. desulfuricans (NCIB8307), Norway 4 strain (NCIB8310), D. gigas (NCIB9332), D. salexigens (NCIB8403), D. vulgaris (NCIB8303), Wandle strain (NCIB8305), Desulfovibrio sp. (Jones, I97I; NCIBI0455), Desulfotomaculum nigrificans (NCIB8395), Desulfotomaculum orientis ( $\mathrm{NCIB8382),} \mathrm{and} \mathrm{Desulfotomaculum} \mathrm{ruminis} \mathrm{(NCIB8453).}$

Staining procedures for light microscopy. The following tests were performed: for intracellular lipid, sudan black method (Burdon, I946); for volutin, a modified Neisser's method and the method of Laybourne (Cruickshank, I965); for polysaccharide, the periodic acid Schiff method (Hotchkiss, 1948). The presence of spores was investigated by using the malachite green technique (Ashby, 1938) and the acid-fast staining method (Cruickshank, 1965).

Electron microscopy of D. gigas. For electron microscopy, D. gigas strain NCIB9332 was grown for three days at $35^{\circ} \mathrm{C}$ in medium B (Jones, 197I). Whole organisms and sections were examined on copper grids coated with $1 \cdot 5 \%(\mathrm{v} / \mathrm{v})$ Parlodion in ethylene dichloride, using an Hitachi HUIIE microscope operating at $75 \mathrm{kV}$ or a Jeol $100 \mathrm{C}$ microscope operating at $80 \mathrm{kV}$. Organisms to be sectioned were fixed by the method of Kellenberger, Ryter \& 
Séchaud (1958), dehydrated by increasing concentrations of ethanol, and embedded in Spurr's (I969) epoxy resin. Sections about $70 \mathrm{~nm}$ thick were cut using a Reichert OMU2 and stained in $7 \%(\mathrm{w} / \mathrm{v})$ aqueous uranyl acetate for $45 \mathrm{~min}$ followed by Reynolds' (I963) lead citrate for $20 \mathrm{~min}$.

Isolation of granules. Growth conditions, harvesting and the method of cell breakage have been described previously (Jones \& Skyring, 1974), but the medium was modified by omission of $\mathrm{H}_{3} \mathrm{BO}_{3}, \mathrm{CuSO}_{4}, \mathrm{KI}, \mathrm{FeCl}_{3}, \mathrm{MnSO}_{4}, \mathrm{Na}_{2} \mathrm{MoO}_{4}, \mathrm{ZnSO}_{4}$ and $\mathrm{CoCl}_{2}$. After breakage, the resultant preparation was centrifuged at $10000 \mathrm{~g}$ for $15 \mathrm{~min}$ and the supernatant fluid discarded. The lower portion of the pellet consisted of white material considered to be identical with the granules (see Discussion). The dark-coloured upper portion, mainly walls, residual metal sulphide and a few unbroken cells, was removed from the white material by washing the pellet with a jet of distilled water. The remaining material was resuspended in distilled water, recentrifuged and washed again. Two repetitions of this procedure removed all but a small amount of the upper portion, which was scraped off. The white material was dried at room temperature over silica gel, gently ground in a mortar, and further dried to constant weight.

Analytical techniques. In the investigation of crystal structure both X-ray and electron bombardment were employed. The Philips X-ray diffractometer had a copper target and nickel filter. Electron diffraction was performed with a JEM 200A electron microscope operating at $200 \mathrm{kV}$.

Infrared spectra were obtained with a Shimadzu IR-27G spectrophotometer using a $\mathrm{KBr}$ pellet prepared in an RIIC die.

For qualitative analysis, emission spectroscopy was carried out between 248 and $360 \mathrm{~nm}$ in a Hilger spectrograph using carbon electrodes.

For quantitative analysis the material was thoroughly homogenized in a mortar. Magnesium was estimated by the method of standard additions using a Varian Techtron AA5 atomic absorption spectroscope with a nitrous oxide-air flame. Total phosphorus was determined by the method of Chen, Toribara \& Warner (1956). The Perkin Elmer $240 \mathrm{CHN}$ analyser was used for carbon analysis. Nitrogen was estimated by Kjeldahl-Nesslerization (King, 195I) and the presence of poly- $\beta$-hydroxybutyric acid was tested for by the method of Law \& Slepecky (196I).

\section{RESULTS}

\section{Occurrence of granules within various strains}

Light microscopy of $D$. gigas revealed intracellular granules, and white material was observed in the deposit obtained by centrifugation of disrupted but not of whole cells. None of the other strains, which had been similarly subcultured for at least 3 years, showed these characteristics.

\section{Appearance of granules within D. gigas}

Not all cells in a culture of $D$. gigas possessed granules. When present, the granules were spherical, variable in position and, under phase-contrast light microscopy, were usually smaller in diameter than the average cell width (Fig. I $a$ ). Although occasionally two or, rarely, three granules per cell were seen even when division was not apparent, there was usually only one per cell. Both staining tests for volutin were positive for the granules; there was no evidence from the specific staining reactions that the granules were spores or consisted of lipid or polysaccharide material. Further evidence that spores were absent was the lack of growth by inocula of organisms which had been heated at $80{ }^{\circ} \mathrm{C}$ for $10 \mathrm{~min}$. 


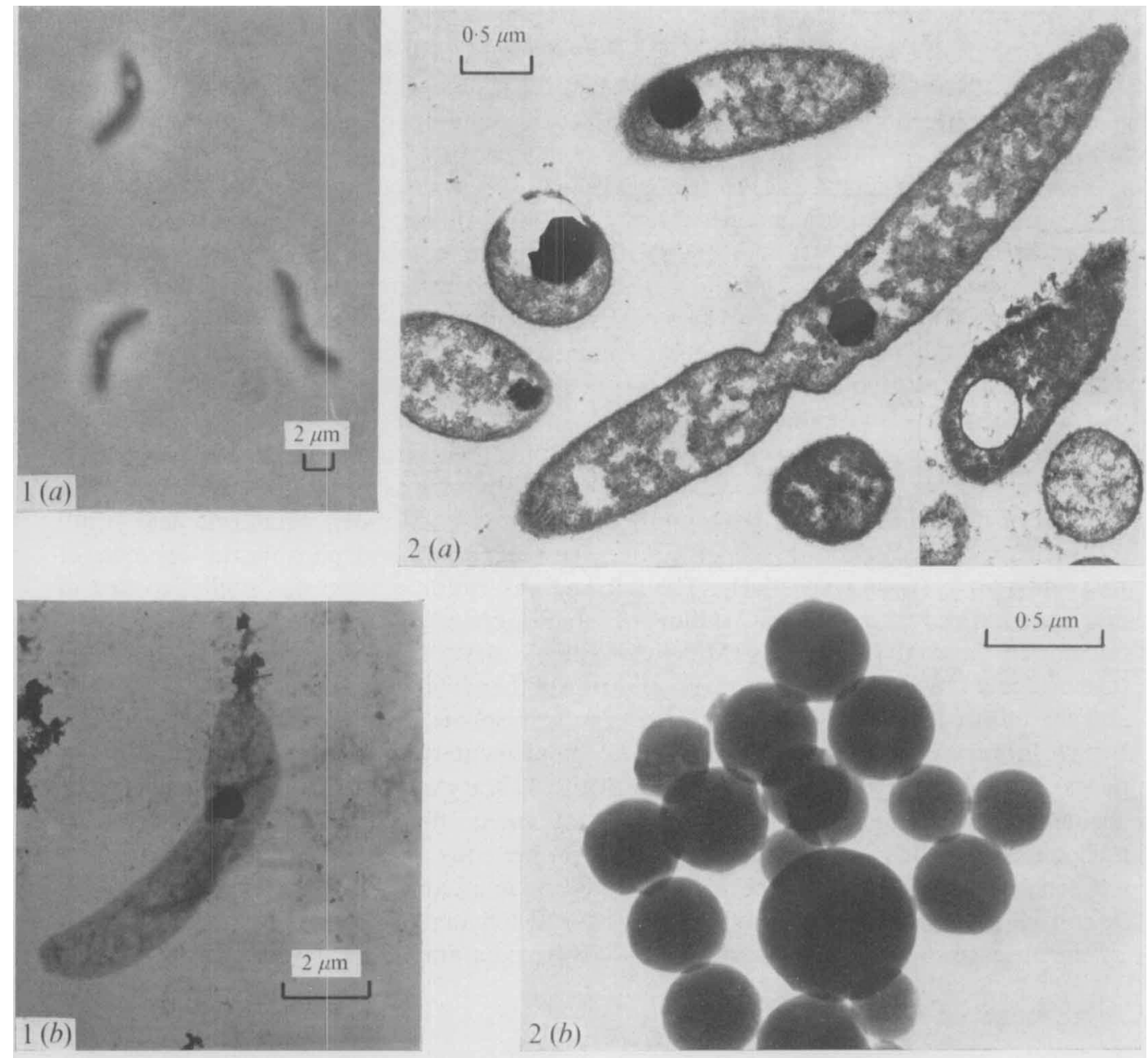

Fig. I. (a) Phase contrast light micrograph of D. gigas showing granules. (b) Electron micrograph of $D$. gigas with intracellular granules.

Fig. 2. (a) Stained sections of D. gigas containing granules. Inset: sectioned organism showing hole. (b) Electron micrograph of isolated granules.

The granules (Fig. I $b$ and $2 a$ ) were electron dense and showed no internal structure; there was no clear evidence for an enclosing membrane. Sectioned organisms (Fig. $2 a$ ) frequently showed holes which could indicate partial or complete removal of the granules during sectioning.

\section{Solubility of granules}

The white material was insoluble in water, I M-sodium hydroxide, ethyl alcohol, acetone, ether, chloroform, benzene, carbon tetrachloride and carbon disulphide. It was almost completely soluble in $\mathrm{M}-\mathrm{HCl}$, but a slight deposit remained which appeared visually to be organic. In perchloric acid $(70 \%, w / w)$, complete solution occurred. 


\section{Chemical and physical analysis of granules}

Electron microscopy (JEM 200A) showed that the gently ground white material consisted of spheres 0.2 to $0.8 \mu \mathrm{m}$ in diameter (Fig. $2 \mathrm{~b}$ ), corresponding in appearance to the intracellular granules.

$X$-ray diffraction analysis gave two peaks with inter-reticular spacings of $0.59 \mathrm{r}$ and $0.298 \mathrm{~nm}$ which were of low intensity, very broad and diffuse. No difference was obtained with material which had lost $20 \%(\mathrm{w} / \mathrm{w})$ after heating to constant weight at $109{ }^{\circ} \mathrm{C}$. These results suggest that the white material was very close to being amorphous, with an extremely fine grain size. The presence of only two peaks is indicative of some repetition of structure in one direction only. The only diffraction feature of the electron diffraction pattern was a diffusion ring corresponding to an inter-reticular spacing of $0.3 \mathrm{I} \mathrm{nm}$. This also implies that the material was essentially amorphous.

Emission spectroscopy showed magnesium and phosphorus to be present in large amounts with traces of $\mathrm{Na}, \mathrm{Ni}, \mathrm{Ca}, \mathrm{Co}, \mathrm{Si}, \mathrm{Fe}$ and $\mathrm{Cu}$. Sulphur was not detected. Quantitative analysis of the white material (Io $\mathrm{mg}$ ) after solution in $70 \%(\mathrm{w} / \mathrm{w})$ perchloric acid ( $\mathrm{I} \mathrm{ml})$ followed by $\mathrm{I}$ M-hydrochloric acid $(99 \mathrm{ml}$ ) gave magnesium and phosphorus contents of 10.4 and $15.5 \%(\mathrm{w} / \mathrm{w})$ respectively. The infrared absorption pattern was similar to that of magnesium tripolyphosphate and sodium tripolyphosphate (Corbridge \& Lowe, I954, 1955), but not to those of phosphates (Miller \& Wilkins, 1952) or other condensed phosphates (Corbridge \& Lowe, 1955). The infrared spectrum of the white material isolated from D. gigas, and the infrared spectrum of magnesium tripolyphosphate, have been deposited with the British Library at Boston Spa, Yorkshire, as Supplementary Publication No. SUP 2800 I (3 pages). Copies may be obtained from the British Library on demand. Requests should be accompanied by prepaid coupons (held by many universities and technical libraries) or by a cheque for $25 \mathrm{p}$ (65p to Europe, $75 \mathrm{p}$ elsewhere) per copy.

Carbon was present in the organic form only and in an amount $(6.3 \%$, w/w) too large to be considered as contamination from any residual cell material. This was further emphasized by the absence of nitrogen. Tests for poly- $\beta$-hydroxybutyrate were negative.

\section{DISCUSSION}

Evidence that the intracellular granules in D. gigas and the dense white material obtained from extracts were identical is threefold: (i) the white material was intracellular since it was not observable in centrifuged deposits of unbroken organisms; (ii) none of the other dissimilatory sulphate-reducing bacteria which were studied exhibited granules or gave white material after cell breakage and centrifugation; (iii) the shape and size of the components of the white material before thorough crushing were similar to those of the intracellular granules.

In electron micrographs of whole cells or sections of $D$. gigas the granules showed characteristics which Harold (I966) has described as 'diagnostic' for polyphosphate. Also, the positive metachromatic staining, although perhaps not specific for polyphosphate (Martinez, 1963), together with the additional evidence of chemical analysis and infrared spectra, strongly suggested that the granules contained polyphosphate. The molar ratio of phosphorus to magnesium of $I \cdot I 7$ was almost precisely that for magnesium tripolyphosphate, $\mathrm{Mg}_{5}\left(\mathrm{P}_{3} \mathrm{O}_{10}\right)_{2}(\mathrm{I} \cdot 2)$. In addition, the infrared absorption spectrum of the white material differed little from that of magnesium tripolyphosphate. The slight differences might result from the presence of organic matter in the white material. A variety of organic material has 
been reported in association with bacterial polyphosphate inclusions (Harold, 1966), but the nature of the organic component in the granules of $D$. gigas and of its association with the polyphosphate are unknown. Poly- $\beta$-hydroxybutyric acid is known to be stored in some bacteria (Lemoigne, 1927; Macrae \& Wilkinson, 1958; Fossyth, Hayward \& Roberts, 1958; Doudoroff \& Stanier, 1959; Mulder \& Van Veen, I963; Tobback \& Laudelout, 1965; Reichelt \& Baumann, 1973), and has also been shown as the principal component of granules which show a metachromatic reaction within Spirillum volutans (Martinez, 1963), but was not detected as a constituent of the white material from $D$. gigas.

Electron micrographs of thin sections of $D$. gigas showed holes (Fig. $2 a$ ) similar to those frequently observed in other organisms (Harold, 1966) and also some granules which appeared to have been partially displaced from their original site. The fragmentation and 'slip' which were evident suggested a displacement during sectioning rather than the volatilization at high electron beam intensity which may have occurred with other material (Sicko, 1972). Although polyphosphate granules are very common in micro-organisms, the inclusions in D. gigas appeared to be of unusually short-chain polyphosphate, and to be unique in their ready isolation after cell breakage (Harold, 1966). Both features may have been the result of the magnesium content, since magnesium not only precipitates tripolyphosphate but may also have caused degradation of higher molecular weight polyphosphate (Thilo, I962).

In other organisms polyphosphate accumulation occurs during periods of slow growth, either in older cells or as a result of nutritional imbalance (Harold, I966). Sulphate limitation, for example, has been reported to induce polyphosphate formation in Aerobacter aerogenes (Harold \& Sylvan, 1963), but this is unlikely to be associated with granule formation during growth of $D$. gigas since sulphate is a major substrate. There was no indication that the granules were associated with a specific bacterial structure, and their formation was still observed when the concentrations of magnesium and phosphorus in the growth medium (Jones, I97I) were reduced by $90 \%(\mathrm{w} / \mathrm{v})$ or when pyruvate replaced lactate as the carbon and energy source.

It has been suggested that polyphosphate accumulation could be an energy storage mechanism or that its accumulation and subsequent utilization could serve to regulate the phosphorus cycle, but Harold (I966) concluded from experiments with mutants of Aerobacter aerogenes that since the inability to accumulate polyphosphate caused no major growth retardation, polyphosphate was not an essential metabolite. It is not apparent what role, if any, the granules could play in the life processes of $D$. gigas, especially since they do not occur inside every organism and were not present when the bacterium was first obtained from NCIB. These facts, and the absence of the granules in representatives of all other known species of sulphate-reducing bacteria which had been similarly subcultured, indicate that they have no relevance to the process of dissimilatory sulphate reduction. Whether the granules accumulate by an enzymic process or precipitate chemically remains to be determined. Certainly, no indication of their origin can be obtained from their position within cells, which is variable.

We are indebted to T. H. Donnelly, Baas Becking Laboratory, Canberra, for atomic absorption analyses and to Ms C. Gardner, Bureau of Mineral Resources for X-ray diffraction analyses. Thanks are also due to R. McDonald, Australian Microanalytical Service, Division of Applied Chemistry, C.S.I.R.O., and University of Melbourne for carbon analysis, to Ms J. Picker, Research School of Biological Sciences, A.N.U., Canberra, for electron microscopy of organisms, and to Dr J. Sanders, Tribophysics, University of Melbourne, for electron diffraction and electron microscopy of granules. The skilled technical 
assistance of Ms W. Byrne is also acknowledged. The Baas Becking Geobiological Laboratory is supported by the Bureau of Mineral Resources, the Commonwealth Scientific and Industrial Research Organization and the Australian Mineral Industries Research Association Ltd.

\section{REFERENCES}

AshBy, G. K. (1938). Simplified Schaeffer spore stain. Science, New York 87, 443.

BURDON, K. L. (1946). Fatty material in bacteria and fungi revealed by staining dried, fixed slide preparations. Journal of Bacteriology 52, 665-678.

Chen, P. S., Jun., Toribara, T. Y. \& Warner, H. (1956). Microdetermination of phosphorus. Analytical Chemistry 28, $1756-1758$.

CoRbridge, D. E. C. \& LOWE, E. J. (1954). The infra-red spectra of inorganic phosphorus compounds. Journal of the Chemical Society, 493-502.

CORBRIDGE, D. E. C. \& LowE, E. J. (1955). Quantitative infrared analysis of condensed phosphates. Analytical Chemistry 27, I383-1387.

Cruickshank, R. (1965). Medical Microbiology, I Ith edn. Edinburgh and London: E. and S. Livingstone.

DOUDOROFF, M. \& STANIER, R. Y. (1959). Role of poly- $\beta$-hydroxybutyric acid in the assimilation of organic carbon by bacteria. Nature, London 183 , 1440-I 442 .

Forsyth, W. G. C., HaYward, A. C. \& RoberTS, J. B. (1958). Occurrence of poly- $\beta$-hydroxybutyric acid in aerobic Gram-negative bacteria. Nature, London 182, 800-80I.

HAROLD, F. M. (1966). Inorganic polyphosphates in biology: structure, metabolism, and function. Bacteriological Reviews 30, 772-794.

Harold, F. M. \& Sylvan, S. (1963). Accumulation of inorganic polyphosphate in Aerobacter aerogenes. II. Environmental control and the role of sulfur compounds. Journal of Bacteriology 86, 222-23I.

HotchKiss, R. D. (1948). A microchemical reaction resulting in the staining of polysaccharide structures in fixed tissue preparations. Archives of Biochemistry 16, I3I-I4I.

JoNES, H. E. (197I). Sulfate-reducing bacterium with unusual morphology and pigment content. Journal of Bacteriology 106, 339-346.

JONES, H. E. \& SKYrING, G. W. (1974). Reduction of sulphite to sulphide catalysed by desulfoviridin from Desulfovibrio gigas. Australian Journal of Biological Sciences 27, 7-14.

Kellenberger, E., Ryter, A. \& SÉCHAUd, J. (1958). Electron microscope study of DNA-containing plasma. II. Vegetative and mature phage DNA as compared with normal bacterial nucleoids in different physiological states. Journal of Biophysical and Biochemical Cytology 4, 67I-682.

KING, E. J. (195I). Micro Analysis in Medical Biochemistry. London: J. and A. Churchill.

LAW, J. H. \& SLEPECKY, R. A. (I96I). Assay of poly- $\beta$-hydroxybutyric acid. Journal of Bacteriology 82, 33-36.

LEMOIGNE, M. (I927). Études sur l'autolyse microbienne origine de l'acide $\beta$-oxybutyrique formé par autolyse. Annales de l'Institut Pasteur 4I, I48-165.

MACrAE, R. M. \& WiLkinson, J. F. (1958). Poly- $\beta$-hydroxybutyrate metabolism in washed suspensions of Bacillus cereus and Bacillus megaterium. Journal of General Microbiology 19, 210-222.

Martinez, R. J. (I963). On the nature of the granules of the genus Spirillum. Archiv für Mikrobiologie 44, 334-343.

Miller, F. A. \& Wilkins, C. H. (1952). Infrared spectra and characteristic frequencies of inorganic ions. Analytical Chemistry 24, I253-1294.

MULDER, E. G. \& VAN VEen, W. L. (1963). Investigations of the Sphaerotilus-Leptothrix group. Antonie van Leeuwenhoek 2, I 2 I-1 53 .

Reichelt, J. L. \& Baumann, P. (1973). Taxonomy of the marine, luminous bacteria. Archiv für Mikrobiologie 94, 283-330.

REYNoLDS, E. S. (1963). The use of lead citrate at high $\mathrm{pH}$ as an electron-opaque stain in electron microscopy. Journal of Cellular Biology 17, 208-212.

Sicko, L. M. (1972). Structural variations of polyphosphate bodies in blue-green algae. Proceedings of the Electron Microscopy Society of America 30, $218-219$.

SPURR, A. R. (1969). A low viscosity epoxy resin embedding medium for electron microscopy. Journal of Ultrastructure Research 26, 3I-43.

THILO, E. (1962). Condensed phosphates and arsenates. Advances in Inorganic Chemistry and Radiochemistry 4, I-77.

TobBack, P. \& LaUdelout, H. (1965). Poly- $\beta$-hydroxybutyric acid in Nitrobacter. Biochimica et biophysica acta 97, 589-590. 